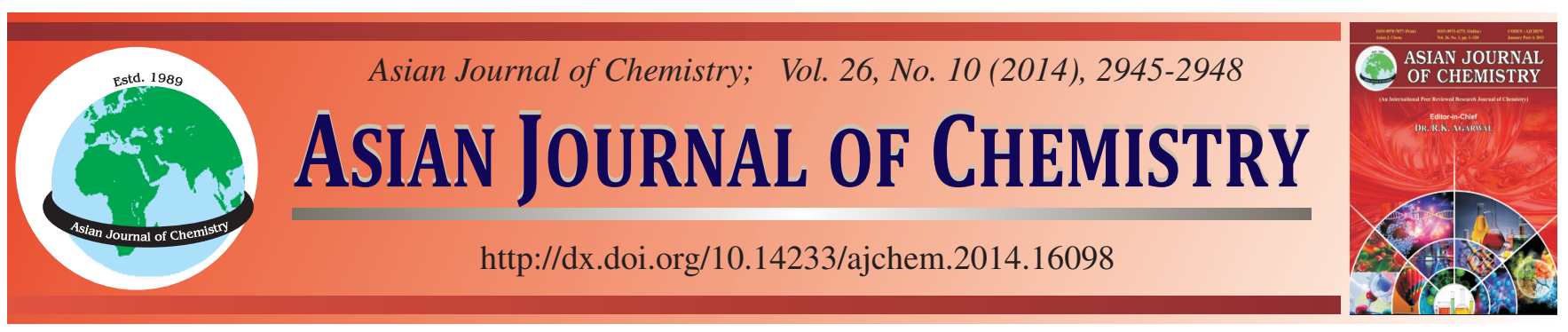

\title{
Biodegradation of Textile Dye by Indigenously Isolated Bacteria Bacillus and Pseudomonas Sp. and Their Discard After Bio-Treatment
}

\author{
Rashid Mahmood ${ }^{1}$, Sikander Ali ${ }^{2}$, Muhammad Umar Hayyat $^{1}$, Faiza Sharif $^{1}$, \\ Tanzeem Akbar CheEma ${ }^{3}$, Abdul Wahid ${ }^{4}$ and Faroog Ahmad ${ }^{1, *}$
}

${ }^{1}$ Sustainable Development Study Centre, Government College University, Lahore, Pakistan
${ }^{2}$ Institute of Industrial Biotechnology, Government College University, Lahore, Pakistan
${ }^{3}$ Department of Botany, Government College University, Lahore, Pakistan
${ }^{4}$ Department of Environmental Sciences, Bahauddin Zakariya University, Multan, Pakistan

*Corresponding author: Tel: +92 300 4654450; E-mail: fagondal82@yahoo.com

\begin{abstract}
Indigenous bacterial isolates of Bacillus and Pseudomonas sp. were used to biodegrade the textile dye (light green) in the laboratory. The 50,100 and $150 \mathrm{ppm}$ of textile dye light green were completely decolorized after $24 \mathrm{~h}$, while $200 \mathrm{ppm}$ after $30 \mathrm{~h}$ of incubation. Both the isolates decolorized 76 to $79 \%$ of dye after $24 \mathrm{~h}$ at pH 7 to 7.5 and temperature $37^{\circ} \mathrm{C}$. The crude enzyme extract of these isolates was also employed for decolorization of textile dye. Crude enzyme extract $0.5,1$ and $1.5 \mathrm{~mL}$ of Bacillus sp. showed 10, 45 and $74 \%$ of decolorization, while 2 and $2.5 \mathrm{~mL}$ showed $100 \%$ decolorization. Bacterial elimination was also done by inducing acetic acid stress. The results indicated that both the indigenous bacteria showed colony forming ability (CFA) after $36 \mathrm{~h}$ only when the concentration of acetic acid was $20 \mathrm{mM}$ and further higher concentration did not favored colony forming ability. Even the incubation of $60 \mathrm{mM}$ of acetic acid for $24 \mathrm{~h}$ was not favorable for colony forming ability which indicates the elimination of bacteria due to acetic acid stress. The relative sensitivity of Sorghum vulgare Pers. CV SSG5000 towards the textile dye and its biodegraded products were studied. Thus, phytotoxicity studies revealed that the biodegradation of the textile dye by the Bacillus and Pseudomonas sp. led to detoxification of the textile dye light green. In conclusion, the use of indigenous bacterial isolates had great potential for the biodegradation of textile dyes.
\end{abstract}

Keywords: Decolorization, Crude enzyme, Acetic acid, Germination, Phytotoxicity.

\section{INTRODUCTION}

Textile wastewater is the major problem in the world as production of colorant reached $8 \times 10^{6} \mathrm{~kg}$ per year, of which 10 $15 \%$ goes into effluents during different textile processes ${ }^{1,2}$. These colorants are primarily designed to resist fading of colour in the presence of intense light and moisture conditions to make good quality fabric. Discharge of such dyes in wastewater is a great threat to the natural ecosystems because these are toxic as well as carcinogenic. Thus, there is a dire need to develop a cost effective strategy to deal with such dyes which are harmful to life $\mathrm{e}^{3,4}$. In this scenario, biological processes to treat such dyes could be environment friendly and cost effective procedures ${ }^{5}$. For example, degradative enzymes can be utilized to degrade textile effluents. These enzymes have low energy requirement, minimum operation cost and eco-friendly nature which make them suitable for such treatments. Laccases are the enzymes which are used for biotreatment of dyestuffs. Information regarding effluent treatment by lacases is available in the literature but potential of other enzymes such as oxidases and reductases is yet to be explored ${ }^{1}$.
The textile effluents treated with enzymes can be reused in dying processes ${ }^{2,6}$. A number of bacterial species belonged to genera Bacillus, Exiguobacterium, Lysinibacillus, Micrococcus, Proteus, Pseudomonas, Sphingomonas and Staphylococcus were reported to be used efficiently in bio-treatment of textile dyes $^{2,7-10}$. But it is essential to eliminate these indigenous bacteria after the bio-treatment of textile effluents prior to discharge. For this purpose suicidal genes were used which were also risky to the environment. Moreover, environmental stresses like weak acid, oxidative stress, antibiotics and heat can be used to eliminate such indigenous bacteria. Among them the use of weak acid is a good choice because of simplicity of its usage and being economical. Acetic acid is widely used as preservative to prevent microbial growth on food stuff and can be used for programmed cell death ${ }^{11}$.

Considering the reported information in the present study we isolated indigenous bacteria to bio-decolorize the textile dye (light green), while acetic acid was used in low concentrations for the removal of indigenous bacteria. 


\section{EXPERIMENTAL}

Wastewater, sludge and affected soil samples were collected in screw capped sterilized bottles for the isolation of bacterial strains from Hudiara drain near Nishat Mills Limited, Ferozepur Road, Lahore, Pakistan. One sample of soil, four samples of sludge and four samples of wastewater were collected from 0 , 5, 500 and 1000 meter away from the main outlet ${ }^{12}$.

Isolation, screening and identification of the indigenous bacterial isolates: The isolation of indigenous bacteria was carried out through serial dilution method using nutrient agar medium $^{13,14}$. Isolated bacterial strains were screened out by incubating them on nutrient agar medium containing various concentrations of textile dye light green 50, 100, 150 and 200 ppm. The stock cultures of screened bacterial isolates were maintained on the nutrient agar medium and stored at $4{ }^{\circ} \mathrm{C}$. The screened bacterial strains were identified on morphological, biochemical and physiological properties following the protocol given in Bergey's Manual of Determinative Bacteriology ${ }^{15}$.

Bio-decolorization and bio-degradation characterization: Decolorization ability of bacterial isolates was analyzed by using spectrophotometer (SpectroScan 80D UV-visible) at optimum wavelength $340 \mathrm{~nm}$. The experiments for decolorization were performed at $\mathrm{pH} 7$ to 7.5 and temperature $37^{\circ} \mathrm{C}$ on nutrient broth (in triplicates). The decolorization activity was expressed in terms of percentage decolorization using the following formula ${ }^{16}$ :

$$
\text { Decolorization }(\%)=\frac{A_{o}-A_{f}}{A_{o}} \times 100
$$

where $\mathrm{A}_{\mathrm{o}}$ is initial absorbance and $\mathrm{A}_{\mathrm{f}}$ is absorbance at incubation time.

HPLC (SHAMZDU-LC20AT) was used to characterize the biodegraded metabolites of light green dye. The analysis was carried out on column $\mathrm{C}_{18}$ with methanol:acetonitrile (1:1) as mobile phase at one milliliter per minute flow rate and used UV detector at $254 \mathrm{~nm}^{17}$.

Enzymatic decolorization of textile dye: The bacterial cells were harvested by centrifugation at $8000 \mathrm{rpm}$ for $10 \mathrm{~min}$ and then washed with $10 \mathrm{mM}$ phosphate buffer of $\mathrm{pH} 7$. It was then suspended in $50 \mathrm{mM}$ phosphate buffer of same $\mathrm{pH}$. The cells were sonicated (cold) for $15 \mathrm{~min}$ at $70 \%$ amplitude to disrupt the bacterial cells. The cell fragments were removed by centrifugation at $15,000 \mathrm{rpm}$ for $20 \mathrm{~min}$. The supernatant was used as crude enzyme extracts (CEE) and dissolved in $10 \mathrm{~mL}$ of $50 \mathrm{mM}$ phosphate buffers. The enzyme assays was carried out in a cuvette $(4 \mathrm{~mL})$. One hundred ppm of light green dye was mixed in $100 \mathrm{~mL}$ phosphate buffer $(50 \mathrm{mM})$.
The crude enzyme extract (CEE) was taken $0.5,1.0,1.5,2$ and $2.5 \mathrm{~mL}$ in cuvettes separately and then $1 \mathrm{~mL}$ of dye was added in all the cuvettes. Absorbance was measured at $340 \mathrm{~nm}$ after $0.5 \mathrm{~h}$ using spectrophotomer. One unit of enzyme activity was defined as the amount of enzyme required to decolorize $1 \mathrm{ppm}$ of dye in $0.5 \mathrm{~h}$ under the assay conditions $(\mathrm{pH} 7$ and temperature $37^{\circ} \mathrm{C}$ ). All the assays were conducted in triplicate ${ }^{2}$.

Bacterial elimination by induced environmental stress: Bacterial elimination was done by inducing acetic acid stress. The concentrations of acetic acid (0, 20, 40, 60, 80, 100,120, 140 and $160 \mathrm{mM}$ ) were prepared and added separately in isolated cultures on nutrient broth medium. These cultures were spread on nutrient agar after 12, 24 and $36 \mathrm{~h}$ to ascertain the colony forming ability (CFA) by which bacterial elimination was assessed indirectly ${ }^{11}$.

Phytotoxicity studies: In order to ascertain the toxicity of dye and biodegraded metabolites, phytotoxicity tests were performed on Sorghum vulgare Pers. CV SSG5000. The biodegraded metabolites of light green dye were extracted and dissolved in $10 \mathrm{~mL}$ distilled water for these tests. The phytotoxicity tests were carried out on seeds of sorghum (20 seeds), a common agricultural crop of Pakistan. The study was carried out at room temperature by watering $5 \mathrm{~mL}$ of dye. Control set was carried out using irrigation water at the same time. Germination $(\%)$, plumule and radical length $(\mathrm{cm})$ were recorded after 7 days 9 .

\section{RESULTS AND DISCUSSION}

Bio-decolorization and bio-degradation of textile dye: Morphologically distinct colonies were observed and found that 21 showed growth (50 ppm light green dye) out of total 76 colonies. All the 21 morphologically distinct colonies were screened at 100, 150 and $200 \mathrm{ppm}$ light green dye. The isolate number 1, 3, 5, 7, 9 and 20 were screened on the basis of their ability to degrade the dye efficiently (more than $60 \%$ ) within $24 \mathrm{~h}$. Among these, isolate number 5 and 9 were used for this study and were identified as Bacillus and Pseudomonas sp., respectively by standard physiological, morphological and biochemical tests following the protocol given in Bergey's Manual of Determinative Bacteriology ${ }^{15}$. The bacterial isolates Bacillus and Pseudomonas sp. showed remarkable performance towards bio-decolorization of textile dye. The 50,100 and $150 \mathrm{ppm}$ of textile dye were completely decolorized after $24 \mathrm{~h}$ while $200 \mathrm{ppm}$ after $30 \mathrm{~h}$ by Bacillus and Pseudomonas sp. Both the isolates decolorized 76 to 79 $\%$ of dye after $24 \mathrm{~h}$ at $\mathrm{pH} 7.0$ to 7.5 and temperature $37^{\circ} \mathrm{C}$ (Table-1).

TABLE-1

BIO-DECOLONIZATION (\%) OF TEXTILE DYE (LIGHT GREEN) WITH RESPECT TO TIME AND CONCENTRATION OF THE DYE

\begin{tabular}{|c|c|c|c|c|c|c|}
\hline \multirow{2}{*}{ Sr. No. } & \multirow{2}{*}{ Bacterial isolates } & \multicolumn{5}{|c|}{ Bio-decolonization (\%) } \\
\hline & & Time (h) & $50 \mathrm{ppm}$ & $100 \mathrm{ppm}$ & $150 \mathrm{ppm}$ & $200 \mathrm{ppm}$ \\
\hline \multirow{3}{*}{1} & \multirow{3}{*}{ Bacillus sp. } & 12 & 64 & 62 & 58 & 54 \\
\hline & & 24 & $\mathrm{~cd}$ & $\mathrm{~cd}$ & $\mathrm{~cd}$ & 79 \\
\hline & & 30 & ee & ee & ee & $\mathrm{cd}$ \\
\hline \multirow{3}{*}{2} & \multirow{3}{*}{ Pseudomonas sp. } & 12 & 67 & 64 & 59 & 51 \\
\hline & & 24 & $\mathrm{~cd}$ & $\mathrm{~cd}$ & $\mathrm{~cd}$ & 76 \\
\hline & & 30 & ee & ee & ee & $\mathrm{cd}$ \\
\hline
\end{tabular}

cd = complete decolorization, ee $=$ end of experiment 
The HPLC analysis of textile dye collected at $0 \mathrm{~h}$ of incubation showed peak at $2.622 \mathrm{~min}$. After $24 \mathrm{~h}$ of incubation, when maximum biodegradation had occurred, five major peaks were observed at 2.802, 3.113, 3.480, 8.849 and $8.931 \mathrm{~min}$, which showed that a single compound after bio-degradation reduced to five different compounds (Fig. 1a, b). The textile dyes indisputably pass on high load of carcinogenic and mutagenic pollutants to the aquatic ecosystems. Bioremediation being eco-friendly is preferred over the conventional effluent treatment methods because they have high operational cost and produce much more sludge ${ }^{18}$. In this study indigenous isolated bacteria Bacillus and Pseudomonas sp. were used to bio-decolorize textile dye. The results revealed the efficacy of Bacillus and Pseudomonas sp. for the bio-decolorization and biodegradation of textile dye is quite significant. It also makes these isolates as potential candidates for commercial applications. Various researchers have already conducted bioremediation studies using other textile dyes. They obtained similar results for decolorization of orange T4LL, reactive orange16 and Congo red ${ }^{13,17,19}$.
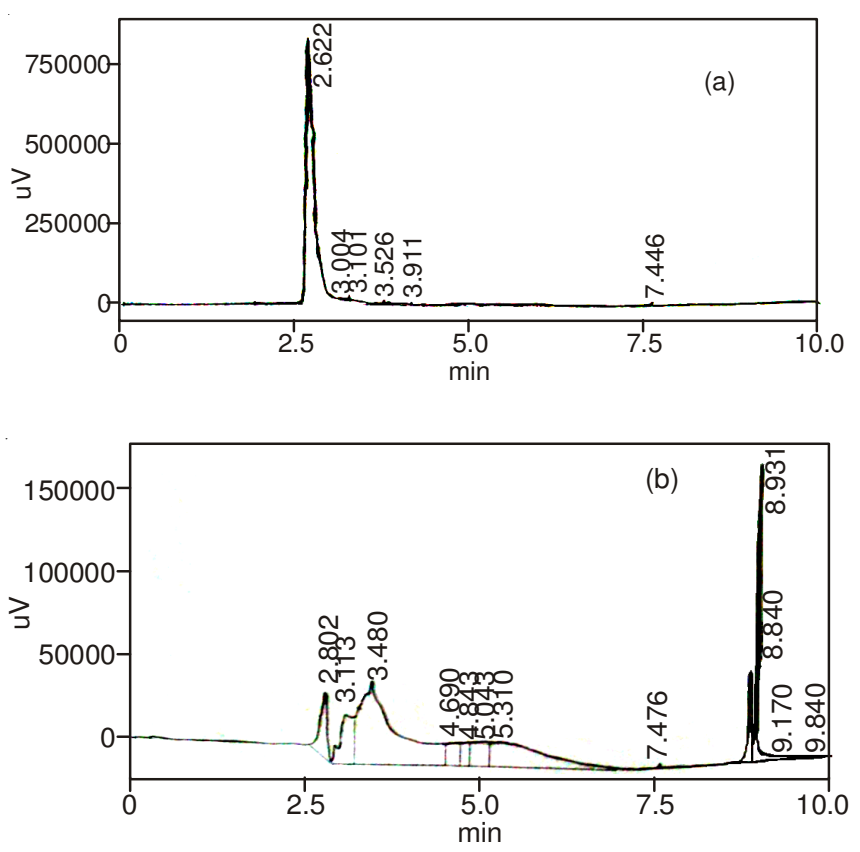

Fig. 1. HPLC chromatogram (a) control textile dye light green at $0 \mathrm{~h}$ (b) degraded metabolites of textile dye light green after $24 \mathrm{~h}$

Enzymatic decolorization of textile dye by crude enzyme extract: The one unit of enzyme activity was defined as the amount of enzyme required to decolorize $1 \mathrm{ppm}$ of dye in $0.5 \mathrm{~h}$ under the assay conditions (at $\mathrm{pH} 7$ and under temperature $37^{\circ} \mathrm{C}$ ). The crude enzyme extract (CEE) $0.5,1.0$, amd $1.5 \mathrm{~mL}$ of Bacillus sp. showed 10, 45 and 74 while $2 \mathrm{~mL}$ and $2.5 \mathrm{~mL}$ showed $100 \%$ decolrization. The crude enzyme extract (CEE) 0.5, 1.0, and $1.5 \mathrm{~mL}$ of Pseudomonas sp. showed 15, 47 and $78 \%$ decolorization while $2 \mathrm{~mL}$ and $2.5 \mathrm{~mL}$ showed $100 \%$ decolorization (Fig. 2). In the decolorization of textile dyes, a number of bacterial enzymes are involved. In fact, bacteria are the source of reductases and oxidases which are used to degrade the dyes. For example, Escherichia coli CD-2 was used to purify an oxygen insensitive azoreductase having characteristics of textile dye degradation. Once a textile dye is reduced by a reductase, it cannot be re-oxidized to form colourant $^{20,21}$. The results indicated that crude enzyme extract decolorized textile dye light green is quite significant making the crude enzyme extract potentially more effective for commercial applications.

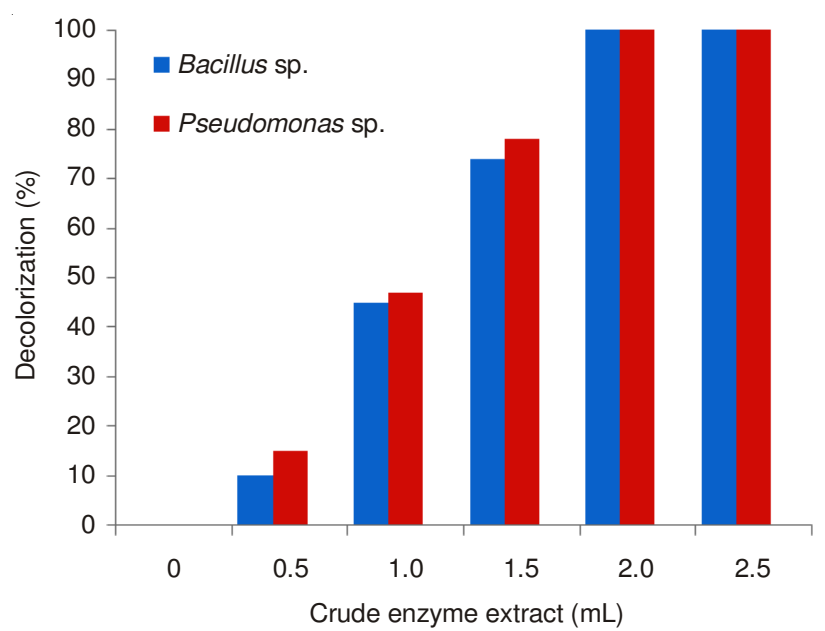

Fig. 2. Decolorization of textile dye light green by crude enzyme extract of Bacillus sp. and Pseudomonas sp

Bacterial elimination by induced environmental stress: Bacterial elimination was done indirectly by inducing acetic acid stress. After $36 \mathrm{~h}$ only $20 \mathrm{mM}$ concentration showed colony forming ability and further higher concentration of acetic acid did not favored colony forming ability. After $24 \mathrm{~h}$ Bacillus sp. showed colony forming ability both at 20 and 40 $\mathrm{mM}$ concentration of acetic acid. Contrary to 36 and $24 \mathrm{~h}$, at $12 \mathrm{~h}$ all the concentration of acetic acid (0, 20, 40, 60, 80, $100,120,140$ and160 mM) exhibit the colony forming ability. Regarding Pseudomonas sp. after 36 h only $20 \mathrm{mM}$ concentration showed colony forming ability and further higher concentration did not favored colony forming ability. In comparison, after $24 \mathrm{~h}$ Pseudomonas sp. showed colony forming ability both at 20 and $40 \mathrm{mM}$. Similar to Bacillus sp. Pseudomonas sp. also exhibited colony forming ability after $12 \mathrm{~h}$ in all concentrations of acetic acid (0, 20, 40, 60, 80, 100, 120 and $140 \mathrm{mM}$ ) (Table-2).

After the decolorization of textile dyes it is necessary to eliminate the used indigenous bacteria prior to discharge into the drain. Usually, environmental stresses like weak acid, oxidative stress, antibiotics and heat can be used to eliminate the indigenous bacteria. Among them the use of weak acid is a better choice because of simplicity of its usage, as well as it is quite economical. Acetic acid is widely used as preservative to prevent microbial growth on food stuff and is mostly used for programmed cell death. Acetic acid enters the bacterial cell by simple diffusion and inside the cell it leads to inhibition of the metabolic activities ${ }^{11}$. It is clear from the results that both the indigenous bacteria (Bacillus sp. and Pseudomonas sp.) showed colony forming ability after $36 \mathrm{~h}$ only at $20 \mathrm{mM}$ concentration of acetic acid and further higher concentration did not favored colony forming ability (Table-2). Even the incubation of $60 \mathrm{mM}$ of acetic acid for $24 \mathrm{~h}$ is not favorable for colony forming ability. Thus, the use of acetic acids stress is quite effective in bacterial elimination. 


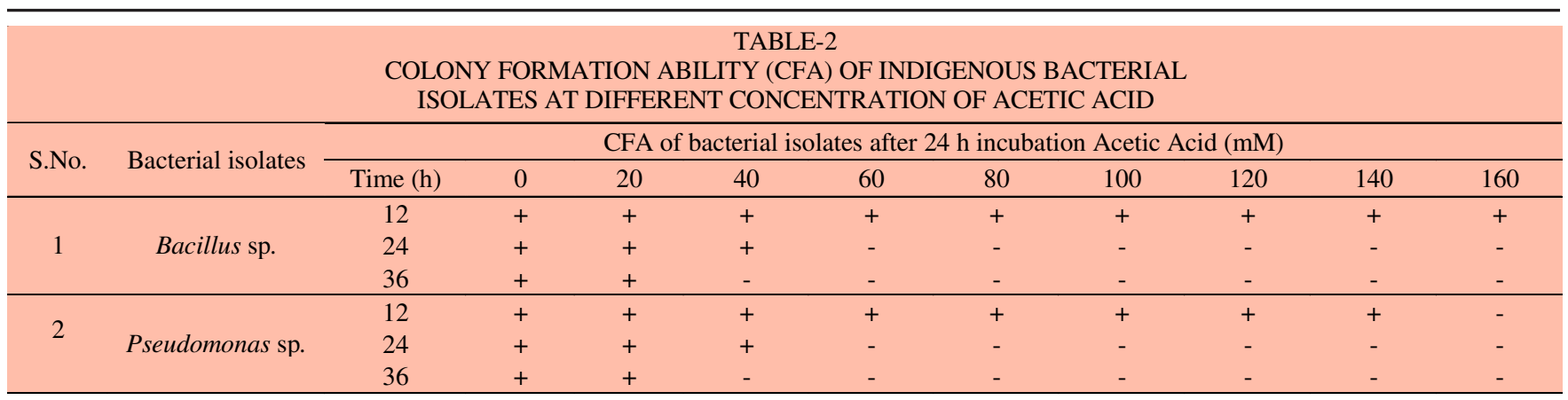

Phytotoxicity studies: Biodegradation of textile dyes leads to production of various kinds of degraded products which could be harmful for plant growth. Therefore, it is virtually important to study the toxicity impact of these biodegraded products on plants. The relative sensitivity of Sorghum vulgare Pers. towards the textile dye light green and its biodegraded products was studied. The plumule and radicle length of Sorghum vulgare was $22 \pm 1.14$ and $6 \pm 0.68 \mathrm{~cm}$, respectively, whereas germination was $100 \%$ in control. The germination was reduced to $36 \%$ when seed were treated with 200 ppm of textile dye light green. Plumule and radicle length of S. vulgare decreased up to $4.3 \pm 0.81$ and $2.3 \pm 0.11 \mathrm{~cm}$ respectively when seed were treated with $200 \mathrm{ppm}$ concentration of green dyes. Similarly, the germination percentage of $S$. vulgare was $97 \%$, Plumule and radicle length was $7.5 \pm 1.01$ and $4.5 \pm$ $1.04 \mathrm{~cm}$, respectively when treated with biodegradation products of textile dye light green (Fig. 3). Results obtained with textile dye light green and its degraded metabolites are in agreement with results reported by Saratale et al. ${ }^{9}$ and Phugare et $a .^{22}$. The results indicated that the extracted degraded metabolites by Bacillus and Pseudomonas sp. gives nontoxic products, resulting in good germination as well as plumule and radicle length of $S$. vulgare as compared to use of textile dye alone. Thus, phytotoxicity studies revealed that the biodegradation of the textile dye light green by the Bacillus and Pseudomonas sp. led to detoxification of the pollutant dyes.

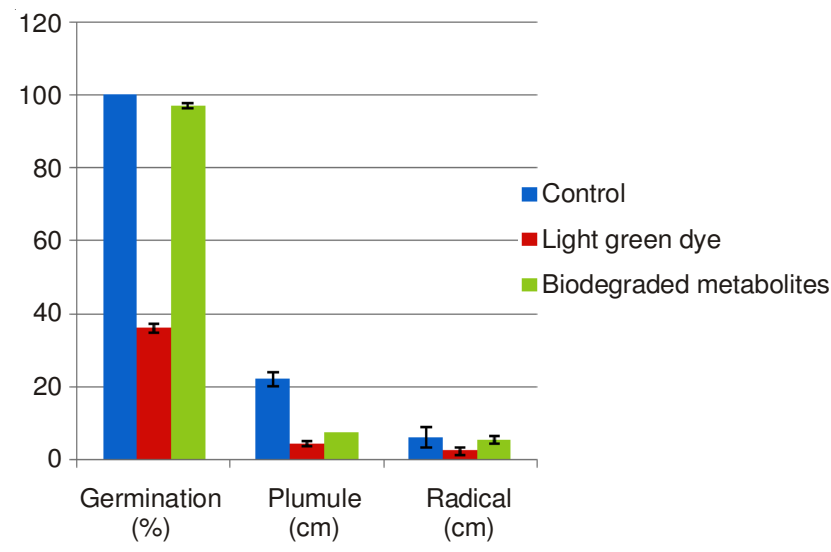

Fig. 3. Phytotoxicity test of treated and untreated textile dye light green

\section{Conclusion}

It is concluded from the present study that the use of Bacillus and Pseudomonas sp. for the removal of textile dye light green could be an effective method, especially when they are eliminated after the treatment by acetic acid. Therefore, it is the most safe and cheaper method for the removal of textile dyes and discarding the bacteria after the bio-treatment.

\section{ACKNOWLEDGEMENTS}

The authors appreciatively acknowledged the Sustainable Development Study Centre, Government College University Lahore for providing the necessary funding to carry out this research for the completion of $\mathrm{Ph}$.D. studies of the first author.

\section{REFERENCES}

1. Y. Liu, J. Huang and X. Zhang, J. Biosci. Bioeng., 108, 496 (2009).

2. Z.W. Wang, J.S. Liang and Y. Liang, Int. Biodeterior. Biodegrad., 76, 41 (2013).

3. A. Kunz, H. Mansilla and N. Duran, Environ. Technol., 23, 911 (2002).

4. H. Wang, J.Q. Su, X.W. Zheng, Y. Tian, X.J. Xiong and T.L. Zheng, Int. Biodeterior. Biodegrad., 63, 395 (2009).

5. K. Jain, V. Shah, D. Chapla and D. Madamwar, J. Hazard. Mater., 213214, 378 (2012).

6. S. Ben Younes and S. Sayadi, J. Mol. Catal. B, 87, 62 (2013).

7. L. Ayed, A. Mahdhi, A. Cheref and A. Bakhrouf, Desalination, 274, 272 (2011).

8. A.N. Kabra, R.V. Khandare and S.P. Govindwar, Water Res., 47, 1035 (2013).

9. R.G. Saratale, G.D. Saratale, D.C. Kalyani, J.S. Chang and S.P. Govindwar, Bioresour. Technol., 100, 2493 (2009).

10. R.G. Saratale, S.S. Gandhi, M.V. Purankar, M.B. Kurade, S.P. Govindwar, S.E. Oh and G.D. Saratale, J. Biosci. Bioeng., 115, 658 (2013).

11. O.M. Gomaa, J. Genet. Eng. Biotechnol., 10, 185 (2012).

12. APHA, Standard Methods for the Examination of Water and Wastewater, American Public Health Association, Washington, DC, USA, edn. 21 (2005).

13. J.P. Jadhav, S.S. Phugare, R.S. Dhanve and S.B. Jadhav, Biodegradation, 21, 453 (2010).

14. A. Kaur, S. Vats, S. Rekhi, A. Bhardwaj, J. Goel, J. Goel, R.S. Tanwar and K.K. Gaur, Procedia Environ. Sci., 2, 595 (2010).

15. J.G. Holt, N.R. Krieg, P.H. Sneath, J.T. Staley and S.T. Williams, Bergey's Manual of Determinative Bacteriology, Williams and Wilkins, Baltimore, edn. 9 (1994)

16. J. Cheriaa, M. Khaireddine, M. Roubhia and A. Bakhrouf, Scientific World J., Article ID 512454 (2012).

17. V.V. Dawkar, U.U. Jadhav, D.P. Tamboli and S.P. Govindwar, Ecotoxicol. Environ. Saf., 73, 1696 (2010).

18. S.S. Ashraf, M.A. Rauf and S. Alhadrami, Dyes Pigments, 69, 74 (2006).

19. A.A. Telke, S.M. Joshi, S.U. Jadhav, D.P. Tamboli and S.P. Govindwar, Biodegradation, 21, 283 (2010).

20. D. Cui, G. Li, D. Zhao, X. Gu, C. Wang and M. Zhao, Process Biochem., 47, 544 (2012)

21. Y. Yang, B. Wei, Y. Zhao and J. Wang, Bioresour. Technol., 130, 517 (2013).

22. S.S. Phugare, D.C. Kalyani, S.N. Surwase and J.P. Jadhav, Ecotox. Environ. Safe., 74, 1288 (2011). 